\title{
CJLT

\section{Online Education: A Science and Technology Studies Perspective \\ Éducation en ligne: Perspective des études en science et technologie}

\author{
Edward C. Hamilton, Capilano University \\ Norm Friesen, Thompson Rivers University
}

\begin{abstract}
This paper argues that research into the pedagogical value and potential of new technologies is limited by the implicit philosophical perspectives on technology that such research adopts. These perspectives either imbue technologies with inalienable qualities (essentialism) or posit technology as a neutral means for realizing goals defined by their users (instrumentalism). Such approaches reflect the reigning common sense around the relation of technology and social practice, but they have also been resoundingly critiqued from within the philosophy, history and sociology of technology. It is our argument that the development of more nuanced philosophical perspectives on technology derived from contemporary technology studies can provide fruitful new directions for online education research. After briefly outlining how essentialist and instrumentalist perspectives operate in such research, we overview the key contributions developed in technology studies, suggesting how the latter might enhance research into online education.
\end{abstract}

\section{Résumé}

Cet article soutient que la recherche sur la valeur et le potentiel pédagogiques des nouvelles technologies est limitée par les positions philosophiques qui y sont implicites. Ces positions conduisent soit à attribuer des qualités inaliénables aux technologies (essentialisme), soit à appréhender la technologie comme un moyen neutre pour la réalisation d'objectifs définis par les utilisateurs (instrumentalisme). De telles approches reflètent le sens commun qui prévaut quant à la relation entre la technologie et la pratique sociale. Elles ont cependant aussi été vivement critiquées dans les milieux de la philosophie, de l'histoire et de la sociologie de la technologie. Nous défendons l'idée que l'élaboration de positions philosophiques plus nuancées sur la technologie, issues des études contemporaines de technologie, peut offrir de nouvelles orientations fécondes pour la recherche consacrée à l'éducation en ligne. Après une brève description des positions essentialistes et instrumentistes telles qu'elles se présentent dans ce champ de recherche, nous passerons en revue les principales contributions des études en 
technologie et suggérons comment ces dernières pourraient rehausser la recherche consacrée à l'éducation en ligne.

\section{Introduction}

In recent years, research into the pedagogical value of network computing and digital media has exploded. As they have elsewhere, these innovations are expected to usher in dramatic changes in education that are seen by many as both unstoppable and beneficial. Administrators value them for the cost-reductions they promise; students love them for their flexibility; pedagogues see in them a reflection of progressive models of education. Amidst this furore, extensive research literatures dealing with online education have emerged in educational technology, distance education, educational philosophy, cognitive science, educational leadership, and the list goes on.

These literatures adopt a variety of perspectives on education - from constructivists searching for authentic educational experiences (e.g., Anderson, 2004), to cognitivists attempting to move learners' mental models from novice to expert levels (e.g., Jacobson, 2004; Royer, 2005), to critical pedagogues hoping to pluralise the classroom (e.g., Lauzon, 1999), to distance educators hoping to add interactivity to distributed learning (e.g., Gunawardena \& McIsaac, 2004), to administrators seeking higher levels of productivity (e.g., Massy \& Wilger, 1998). These literatures, moreover, explore a diversity of questions: how do new technologies transform instructional practices (e.g., Harasim, Hiltz, Teles \& Turoff, 1995; Lankshear, Peters \& Knobel, 2000; Naidu, 2003; Smith, 2002; Steeples \& Jones, 2002); how well do they reflect this or that pedagogical approach (e.g., Ally, 2004; Bonk \& King, 1998; Laurillard, 1993; Stephenson, 2001); in what ways do they enhance cognitive activity or learning experiences (e.g., Brown, Collins \& Duguid, 1996; Kintsch, 2005); what changes in administration do they allow (e.g., Collis, 2002; Davenport, 2002; Foster, Bowskill, Lally \& McConnel, 2002; Lanham, 2002; Moore \& Kearsley, 1996); how do they transform relations between teachers, students and information (e.g., Hiltz, 1994; Holmes \& Gardner, 2006; Wallhaus, 2000)? ${ }^{1}$ Amidst this diversity, a single theme emerges - that the technologies themselves are, indeed, of beneficial value in education.

These benefits are seen as multiple and diverse. For some, online education presages a substitution of "physical processes with new processes that can be accomplished over networks" (Katz \& Oblinger, 2000, p. 2), resulting in flexible, student-driven forms of education. This will lead to an increasing modularisation of customised learning materials catering to the lifelong learning needs of the information economy (Goodfellow, 2007). As the technical capacity for online education develops, the model of physical institutions organized around professional faculty will be replaced by an amorphous "global learning infrastructure" (Heterick, Mingle \& Twigg, 1995) - a "one-stop, Web-based service environment that integrates a range of academic and administrative services" (Graves, 2002, section 4, paragraph 1). This will enable a departure from mass education to "anytime/anywhere" models adaptable to the schedules, needs, and

\footnotetext{
${ }^{1}$ Our references here are meant to be illustrative rather than exhaustive. In the review of online education literature below, we have been selective in the interests of illustrating general tendencies in research dealing with new technologies. We do not mean to ignore the exceptions that exist, but to highlight what we see as dominant perspectives on technology in research into online education.
} 
"cognitive styles" of learners (Fletcher, 2006). A great deal of research on the educational value of new technologies has thus been buoyed by waves of enthusiasm for the technologies themselves, and has been framed by assertions of the inevitable and pervasive changes that will result from their development.

But despite the frequent trumpeting of these claims, it is often the case that new technologies have yielded no significant difference from traditional practices in terms of the enhancement of pedagogical aims, regardless of the underlying pedagogy. ${ }^{2}$ How can this paradoxical phenomenon be explained? On the one hand, it could be said that claims to revolutionary change have been wildly overstated. But such a blanket statement would be of little value to education research. On the other hand, it may be the case that the way in which pedagogical value has been defined in relation to technology has been misguided, leading to an overstatement of their potential for beneficial change and to research that elides a fuller understanding of technologies as social objects. It is this latter aspect of research into online education that we address here and for which we offer a corrective by turning to alternative understandings of technology.

In what follows, we survey two approaches to technology that are often implicit in online education research. The first, which we call "essentialist," takes technologies to be embodiments of abstract pedagogical principles. Here, technologies are depicted as independent forces for the realisation of pedagogical aims that are intrinsic to them prior to any actual use. The second, which we call "instrumentalist," depicts technologies as tools to be interpreted in light of this or that pedagogical framework or principle and measured against how well they correspond in practice to that framework or principle. Here, technologies are seen as neutral means employed for ends determined independently by their users. We argue that, while these approaches reflect much popular opinion on technology, and while they have produced some insights into online education, they fail to grasp the social and historical dimensions of technology. As a result, they cannot adequately ground assessments of its pedagogical value, nor support an appropriate relation between pedagogical practice and technological design.

While both essentialism and instrumentalism have maintained a great deal of currency within discourses of technology, both scholarly and popular, they have largely been discredited by historians, philosophers and sociologists who have developed approaches to technology that can be broadly labelled "constructivist.", Constructivist scholarship abandons essentialist and instrumentalist views and instead crafts analyses that trace the blending of the social and the technical in the development of a variety of technologically-mediated processes. Technology is not independent of society, as essentialism claims, but develops as a concrete response to social interests, claims and values. But neither is technology merely a set of passive tools, as instrumentalism insists - rather, it structures human activity in ways that are not entirely in the control of users. The value of constructivist technology studies thus comes from its ability to grasp the mutual imbrication of social and technical factors within processes of technical development. This allows us to bring debates about pedagogy to the level of technological design and development, while also empowering teachers as social subjects whose business as

\footnotetext{
${ }^{2}$ Cf., e.g., Burton, Moore \& Magliaro (2003), Russell (1999).

${ }^{3}$ Cf., Bijker (1993), Callon (1986, 1987), Feenberg (1999a, 2002), Hughes (1987), Latour (1987), Law (1992), Misa (1992), Pinch \& Bijker (1984). Here we will focus not on any one approach, but on those basic elements that are common to them all.
} 
professionals has always been the crafting of learning processes and environments. As part of our critique of essentialism and instrumentalism, then, we will outline some common elements within constructivist technology studies as a way of introducing a new set of questions into online education research - ones focusing on the dynamic interaction between pedagogy and technology in online education. Throughout, we suggest some ways in which empirical research and philosophical reflection on the educational value of new technologies might be enhanced by a turn towards constructivist approaches. ${ }^{4}$

\section{Essentialist and instrumentalist approaches to online education}

It should be noted that essentialism and instrumentalism are not "theories" of technology if by theory we mean a fully articulated, reflexively employed framework that enables us to interpret and understand some phenomenon. Indeed, it is our argument that a "theory" of technology in this sense is precisely what is missing from the bulk of research into online education. Far from being theories, essentialism and instrumentalism are general orientations that typify many discourses on technology - from journalism to business, from popular representation to academic research. As such, they remain a largely unquestioned background for ascertaining the meaning, nature and importance of technology. In the following discussion we identify the basic elements of this "common sense" and show how it has been active as a framing device for online education.

Essentialism and instrumentalism are typified by a number of assumptions about technology, some shared, some specific to each perspective. Their major shared assumption is that the meaning of technologies is equivalent to what they can do at the level of their overt, predetermined functions. Describing these functions and linking them to standard or expected practices, outcomes or theoretical models in a field of practice can then apparently predict and account for their value in that practice. Such accounts of technology seem reasonable enough, since they draw on the most obvious relationship between human beings and technologies - the ability of the latter to extend or enhance human capacities. The line between human agent and technical thing is established through parallelisms between social, bodily or cognitive functions and the operative parameters of technology. A neat fit thus appears to exist whereby, for essentialists, human capacities are enhanced by technology, or by which, for instrumentalists, technical things transparently correspond to the intentions of users. As we will see, both positions have significant flaws that must be addressed if we are to understand online education as a field of development, research and practice.

\section{Essentialism in online education research}

Essentialism privileges technology itself in assessing its social value. Here, it is expected that technical functionality will lead to the realization of an associated human potential once the technology is in place. In online education research, this approach is evident in the vast number

\footnotetext{
${ }^{4}$ It should be noted that constructivist approaches in technology studies such as the Social Construction of Technology (SCOT) (Bijker, 1993; Pinch \& Bijker, 1984) have been referenced previously as potentially valuable sources of insight for online education, specifically by Kerr (2004). And, of course, Feenberg's work on online education is situated within a constructivist perspective (Feenberg, 2002, 1999b). However, to our knowledge, there has yet been no systematic attempt to outline what constructivist technology studies might contribute to online education research.
} 
of studies that claim an intrinsic connection between learning systems and some school of pedagogical thought and practice - most frequently constructivism or cognitivism. In this light, technologies appear as "constructivist learning environments" (Wilson, 1996), "cognitive tools" (Bereiter, 2002; Scardamalia, 2004), or "mindtools" (Jonassen 1996), assuming an immediate association between technical systems and pedagogical strategies derived from educational philosophy. On the basis of such discursive identifications, the realisation of a pedagogical model or philosophical precept becomes a matter of "plug-and-play" with little reflection on whether the identifications themselves are justifiable at the level of technical structure or pedagogical practice.

The question of justifiability is begged by the simple fact that similar technical functions are often identified with various - even seemingly opposed - pedagogical practices, theoretical models, and conceptual understandings. While, again, the majority of such claims align technology with cognitivist or constructivist learning theory, we can draw on an example linking technology to critical pedagogy:

Cyberspace creates an opportunity for learners to speak their world from their location(s) in a language that is meaningful to them, eliminating the immediate censoring that often takes place in face-to-face education; and allowing others to affirm their words, meanings and understandings. 'Authority' is not so easily able to judge or condemn. In addition, this space allows learners to readily cross borders, to experiment with alternative identities. (Lauzon, 1999, p. 272).

Here we see the typically essentialist depiction of technology as an active agent in the educational process, working independently to create the pedagogical conditions described. While the pedagogical aims outlined here are laudable, the assumption that they are somehow embodied in abstract features of technical systems apart from any specific implementation is questionable. To illustrate, we can turn to a contemporaneous source that identifies the same features with a much different vision of online education:

The global learning infrastructure will encompass a flourishing marketplace of educational services where millions of students interact with a vast array of individual and institutional suppliers. It will be delivered through multiple technologies, including the Internet, broadband cable and satellite [...] It could not have existed five years ago but it will be pervasive five years from now. At the technology core of the global learning infrastructure are fully interoperable modules and an enabling infrastructure which will: extend access to virtually anyone $[. .$.$] provide convenient anytime/anywhere /anyhow$ access $[\ldots]$ deliver high quality, self-paced, customised, world-class content and pedagogy $[\ldots]$ be cost-effective, dramatically reducing the two biggest costs of the current system: faculty and physical plant. [And it will] [c]apitalize on market forces to achieve these goals. (Heterick et al., 1998, p. 4-5).

While the positioning of technology as an active agent is similar, the ends which technology serves are quite different. Rather than fulfilling a social goal of equality amongst participants, technology serves the goal of economic efficiency regardless of the context of learning. The contrast between these two depictions demonstrates the problem with essentialism - namely, the seeming availability of technology for any conceivable end. Indeed, that the same technical infrastructure is seen as a force behind radical politicization and economic rationalization and 
control poses both philosophical and empirical problems that cannot be resolved within the same framework - that is, how are the potentials of technology realized in practice? It is in mistaking the potentials of technology for its essence that essentialism poses its greatest problem for online education research, and which allows such a broad and indeterminate knowledge of educational technology to emerge. As long as there is no analytical means of closing the gap between potential and practice, essentialism leads only to dead ends.

Another feature of essentialist approaches is a tendency to set up absolute oppositions between technology and traditional modes of teaching and learning. This is expressed in dogmatic assertions that the introduction of new technologies necessitates a departure from past practices. ${ }^{5}$ In this formulation, technology is understood as both a symbol and material manifestation of the need "to challenge many deeply held beliefs," to leverage "changes in long established practices" and to encourage "new ways of thinking in an institution" (Bates, 2000, p. 42-3). By contrast, teachers are depicted as conservative, protectionist and hidebound, and their role in the development of online education either downplayed or forgotten. ${ }^{6}$ Implicit here is the idea that teachers have standard and preferred ways of doing things and organizing classroom practices that technologies render obsolete.

While the extension of traditional instruction in technically-mediated environments was considered imperative in early online education (cf. e.g., Feenberg, 1989), in essentialist accounts it is seen as "a restriction that universities must break out of if major advances are to be made" (Holmes \& Gardner, 2006, p. 29). This dovetails well with the rhetoric of technological "revolution" espoused in the popular culture. But the subtle determinism embedded in the notion of technological revolution closes the door to analyses of dynamic relations between traditions in teaching and learning practice, and the design of educational systems. It also has the unfortunate result of alienating faculty from participation in the development of online education and, therefore, of creating an opposition between technology and teachers. Of course, it might be fashionable to deride "traditional" forms of educational practice, but such an attitude fails to recognize the ways in which successful implementation and conduct of online education might draw on traditional modes of teaching and learning (cf, e.g., Hamilton \& Feenberg, 2012).

Overall, essentialism rests on the assumption that technology has independent pedagogical value and that there is little need to do more than embrace it to realize such value. There is a faith here that just because we can make a connection between technical features and the tenets of an educational philosophy, we will actualize that philosophy in practice once we adopt the technical artefact or system. The distance between ideal descriptions and actual practices that results from this perspective may help to explain the "no significant difference" phenomenon. It certainly begs for more concrete analyses of the relationship between technology and pedagogy. It underscores this need by erasing the question of the social mediation of technical functions in the contexts of actual practices. That is, how is practical and professional knowledge of users activated in the contexts of online learning as a means of structuring encounters with and the value of educational technologies? It is here that instrumentalism, in focusing on use, picks up the thread. But does it do any better as a ground for research?

\footnotetext{
${ }^{5}$ Cf., Robertson (2003) for a useful discussion of this opposition in the discourse of educational technology.

${ }^{6}$ For a discussion of the role of faculty in creating online education, see Feenberg (1999b) and Hamilton $\&$ Feenberg (2012 \& 2006).
} 


\section{Instrumentalism in online education research}

Whereas essentialist accounts internalize social functions to technology, instrumentalism privileges users and their pre-defined goals. In instrumentalist accounts of online education, the functional moments of education (delivering content, providing feedback, conducting research, scaffolding, etc.) are described and then linked to the abstract features of a technology. The latter's pedagogical value can then be described as a function of a plan developed in relation to a particular "labour process." In the literature of online education, a whole sub-genre exists that exemplifies this orientation - one combining theoretical depictions of ideal learning situations, functional descriptions of the learning process and typologies of educational tools at the level of their functionality and in relation to the processes so described. ${ }^{7}$ The first moment in such descriptions links educational practice to pedagogical theory, the second gives a functional account of that practice as it is performed by human actors, and the third describes the features of technical systems in the language of those educational functions. The result is a kind of "palette" of educational tools that can be arranged to realize the goals of instructors. Here is where instrumentalism dovetails conceptually with essentialism. Underlying instrumentalist descriptions is a basic assumption that what technologies can do is identical to what instructors and students will do with them once the technologies are introduced. Once education has been rendered in functional terms appropriate to technical description, certain technical features can be focused on in relation to pedagogical theory. In a strangely circular fashion, the pedagogical lens brought to bear on such features acts as evidence of the features' effectiveness.

Typical of this approach is a study by Laurillard (1993), which attempts to describe an ideal learning situation and then to isolate the functional moments of that situation from the perspective of interactions between instructors and students. For Laurillard, the "ideal learning situation" is a one-on-one relationship between instructor and student. This relationship develops out of a series of functional moments of teaching and learning that Laurillard links to a typology of educational media - discursive, adaptive, interactive and reflective. The technologies and systems that fall into each of these categories can thus be mapped onto a pedagogical framework that can apply "to any academic learning situation" (p. 102). While this makes for a convenient turn-key analysis, it fails to recognize the degree to which learning situations vary, the diverse contexts within which education occurs, and (like essentialism) the distance between the potentials of technology and the practice of online education. It also equates the framework of its own analysis (pedagogical theory) with the nature of technology itself. This mistakes tools that are often abstract and ambivalent - available, that is, for a wide variety of purposes - for uniquely educational tools. Instrumentalism thus equates the educational value of technologies with use, rather than attempting to see how pedagogical concerns and considerations might be built into the technology itself at the level of design.

An instrumentalist perspective is also evident in the vast number of case studies that have accompanied the implementation of diverse tools into classroom practice. These take the form of just-so stories about "what happened when I used technology X in course Y to realize pedagogical goal Z." While such an accumulated practical wisdom might assist in identifying

${ }^{7}$ Cf., e.g., Laurillard (1994). 
classroom strategies for specific systems, it does not amount to a theory of the educational value of technology. The isolated nature of such studies ensures a level of specificity that is difficult to transfer to other cases. More importantly, the focus on "use" does not lead to a questioning of the technology itself in relation to identifiable frameworks for teaching and learning. Even if such studies succeed in identifying features that might incidentally correspond to pedagogical strategies, techniques or goals, they do little to break down the barrier separating use from design. Thus they ensure that pedagogical questions are only raised after the fact. Like essentialism, then, instrumentalism cannot provide a basis for understanding how we might integrate technology and pedagogy at the level of design, preferring to stay at the level of use where the form of technology has already been decided.

While the preceding review makes no claims to exhaustiveness, hopefully it illustrates the main lines of thinking on the subject derived from essentialism and instrumentalism. While there may be more sophisticated theorizations of technology in online education research, or at least calls for such (e.g., Gunawardena \& MacIsaac, 2004; Kerr, 2004), the majority of studies implicitly frame technology with respect to instrumentalism or essentialism. We should emphasize that, while these perspectives have produced insights into educational technology, their limitations argue for alternative approaches to the fusion of technology and pedagogy. It is to such alternatives that we now turn.

\section{The critique of essentialist and instrumentalist approaches}

Showing that a field of research is typified by problematic analytical perspectives begs the question of which problems stand in the way of achieving the field's professed aims.

Essentialism and instrumentalism do illuminate something about online education, after all. So why should we critique them or move towards alternative approaches? We claim that the limitations of essentialism and instrumentalism are also the limitations of online education research. This situation hampers understanding of the educational value of new technologies and blinds scholars to potentially fruitful directions for research and analysis.

Since the 1980s, scholars in philosophy, sociology and history of technology have been developing approaches that leave off from the inherent limitations of essentialism and instrumentalism. Through rigorous empirical studies, these scholars demonstrate the limitations of these views and develop frameworks to explain the social construction of technology. In what follows we will illustrate this by focusing on four limitations of essentialism and instrumentalism - their depictions of technology as an independent force or a set of artefacts, their separation of technology and society, their dehistoricisation of technology, and their externalization of human values from technical things. In doing so, we will show how constructivist technology studies addresses these problems and suggests new research directions for online education.

\section{The depiction of technology - opening the black box}

Essentialism and instrumentalism depict technology as either a force or a set of artefacts. These depictions coincide with our everyday experience. Removed as most of us are from technological development, and confronted as we are with seemingly immutable technical things, it is easy to imagine that technologies descend on us from abstract realms of positive knowledge that we 
cannot influence. This view is supported by popular discourses emphasising the near magical nature of technology, with little regard for its origins in social activity. Likewise, because we are surrounded by an array of technical things it is easy for us to identify "technology" as the sum of those things and define it relative to the practical purposes held by users. This, too, is promoted by a popular discourse that displaces technology from view in assessing its consequences (particularly negative ones), instead attributing the latter to human motives. Approaching technology in one of these senses thus conforms to what is most obvious about technology, and supports the adoption of a similar common sense in scholarly research.

However, the technical things with which we are surrounded and which appear as manifestations of Technology are the outcomes of concrete development processes. A technical object cannot be just a set of functions indifferent to particular applications since, in order to exist at all, it has to go through a process whereby its functions and form are delineated in relation to social practices. This process is not mysterious, but merely a particular (if specialized) form of social activity involving the mobilization of technical knowledge in the definition and solving of problems and in the specification of technical functions. What this suggests is that what we call "technology" involves the discursive and interpretive processes out of which technical things emerge. Indeed, technical things are only a surface underneath which teems a complex ecology.

Latour (1987) specifies the difference between technology-as-thing and technology-as-process when he writes of "ready-made" technology versus "technology-in-the-making" (p. 3). Readymade technology comprises the array of finished objects that surround us. Here, technology is treated as a "black box" - a thing whose features we can observe and employ, but which we do not inquire into as to the processes that brought it into existence. Black-boxing technology means taking for granted all the contingent decisions that accumulate behind artefacts and contribute to making them what they are. Both essentialism and instrumentalism do this - the first by removing technology into the realm of autonomous science, the second by reducing it to preestablished functions. Technology thus appears inevitable in the form in which we confront it, and there appears to be no way of influencing it on the basis of concerns that we might have as users. In such a situation, we become, as Heidegger put it, "enframed" by technology constrained in our understandings and actions to the functional parameters placed on our activity by technology (Heidegger, 1977).

However, technological development is open to social analysis, regardless of the degree to which this fact is ignored in popular and scholarly discourse. It is only relative to decision-making at the level of design that the functions of finished technologies make sense. Acknowledging this means we have already left the realm of technology as functional thing and entered that of technology as iterative process. Here, we see that defining and solving problems are not only technical but discursive and interpretative practices through which decisions about the form and function of technologies are dwelt upon and taken. To study "technology-in-the-making" is to analyse the intersection of the discursive and material dimensions of technological development.

This involves "opening the black box" and attending to the processes whereby technical things come into being - why this artefact in this form? The majority of studies of online education confront ready-made technology and fail to ask such questions. This closes off avenues for articulating truly educational technologies - technologies, that is, which are the result of design processes that integrate questions of pedagogical significance rather than posing them after the fact. As researchers trying to understand the pedagogical value of technologies, we should be 
interested not only in what this or that technical artefact or system does, but also where it came from, how it took shape, and whether the influences present in development reflect the pedagogical principles and aims we see as valuable. We should see educational technologies not as abstract forces but as contingent products of social activity, and not just as instrumental means but as moments in ongoing processes of the design of education. In opening the black box and studying educational-technology-in-the-making, we realize that pedagogical principles can be added to the discursive fields within which technical decisions are made and the design process conducted. We need, therefore, to frame research into online education not only at the level of the use of technical artefacts and systems, but at the level of their design. This is because it is not only in use contexts that questions of pedagogy are relevant, but also at the level at which technical functions and features are specified.

\section{The separation of technology and society - the sociotechnical}

Technologies are emergent phenomena, influenced in their development by a range of actors. This insight opens up another problem of essentialism and instrumentalism: their separation of technology and society. Both approaches see technology as an independent realm of pure technical and scientific law, unsullied by the differences, values or interests that typify the social world. In essentialism this is manifest in the deterministic claim that technology drives social practice and change. Humans must adapt to technical demands, while technology, like a Newtonian god, watches unaffected as the drama unfolds. Instrumentalism formulates the same notion differently - technical things serve interests to which those things are transparent. Human motives are added on after the fact in use. But if this is the case, then what difference does technology make other than in relation to pre-articulated interests? Its significance dwindles to zero. In the end, these positions leave us with a paradox - technology is at once an all-powerful determinant and utterly insignificant in the face of human will.

But if we accept that technology is a social process, then we should adopt a different conception of the "relation of technology and society." Essentialism insists that technology changes society from the outside, while instrumentalism considers social factors only after the fact. But as a process, technology is itself thoroughly embedded in the social in three senses. First, technical design is undertaken by people who do not leave their connection to the social world behind at the laboratory gates. Indeed, technical activity is constrained all along the line by a range of factors characterising the institutional contexts of innovation. A health information system will not, for example, be designed independently of the context of health care provision in a society at a particular time, but in interaction with that context. Secondly, as noted above, technical design involves the mobilization of discursive knowledge of the practices to which technologies are applied. For example, the design of an educational technology is impossible without a working definition of education. Such definitions are invested by designers in educational technologies themselves as they specify technical features corresponding to them. Finally, and because of these other points, technologies have a social content in their very form and function because they result from socially inflected decision-making. Designing technology thus also involves designing the society in which technology is to function (Callon, 1987; Latour, 1992, 1987). Or, as Law (1991) puts it "[w] hat appears to be social is in part technical [and] [w] hat we usually call technical is partly social" (p. 10). For all of these reasons, constructivism tends away from presuppositions lying behind phrases like "technology and society" and speaks instead of "heterogeneous engineering" (Callon \& Latour, 1981; Law, 1987), the construction of 
"heterogeneous networks" (Law, 1992), the "seamless web" of technology and society (Hughes, 1987), "sociotechnical ensembles" (Bijker, 1993), or simply "the sociotechnical."

An illustration of this can be drawn from Feenberg (2003), who discusses the design of industrial machines in relation to the regulation of child labour. In our time, we see child labour as a moral problem to be addressed through legislation and the democratic process, and through social institutions like the family and schools. Prior to the mid-nineteenth century, however, child labour was understood as a condition of industrial production. As such, it was a problem that had to be accounted for in the design of machines. Industrial design thus took place under the assumption that, sometimes, people of less developed musculature and smaller stature would operate the machines. It is not the iron rule of efficiency that drives technical design, nor the laws of engineering and science. Rather, what counts as efficiency in design is itself conditioned by the social context in which the laws of science and engineering are applied. Child labour is not only sustained by amoral industrialists, but also by the framing of industrial design in a context that includes a definition of the child as a labourer and that results in an "encoding" of this definition into industrial technologies. ${ }^{8}$ The result is a biased design - a set of machines designed specifically for children to operate. This bias is not, however, immediately "subjective" but is installed as an objective condition of industrial labour through its technical design. The social contexts of technological design - including the wider policy context - are thus crucibles within which seemingly rational decisions are blended with social perspectives.

This example is one among many that illustrate the imbrication of technology and society that is summarized in the notion of the sociotechnical. Technical design takes place under conditions that are not independent of reigning conceptions of the social world and the presuppositions they foster in human actors. The knowledge that designers bring to bear is steeped not only in their education as professionals, but also in their social positions and the impulses that drive their work. And the artefacts they design are not neutral to the social world, but embody significant features of that world and help in large measure to sustain, rationalize and naturalise it for its inhabitants. Child labour, even, can be instituted with reference to a seemingly rational infrastructure for carrying out productive activity.

Keeping these aspects of design in mind, we are led to conduct a different kind of research into online education. Our concerns would be less about ex post facto relationships between functionality and pedagogy and more about the conceptualisation of educational relations and processes operative in the development of educational systems. How is the design process organized to include certain people or perspectives? What pedagogical assumptions are mobilized in design and how do these get embodied in technical functions? What choices are not made and for what reasons? What constraints or conditions are active within the design context and in education itself to compel certain technical decisions rather than others? Who is excluded from the design process and how does this influence the decisions and specifications that get made? These are the kinds of questions that constructivist technology studies encourage us to ask.

\footnotetext{
${ }^{8}$ Cf., Feenberg (2002) for a discussion of the notion of the "encoding" of technology according to a framework of social imperatives or values.
} 


\section{The removal of technology from history - the processes of stabilisation}

Once we understand technology as a socially situated process of making things we must also revise our normal understanding of the history of technology. Essentialism and instrumentalism obscure this history by reducing it to progress. Essentialism sees progress as a historical absolute: human advancement is a natural by-product of technical change. Technologies emerge as adaptive responses to the limits of existing systems through a kind of evolution. These limits are defined through abstract technical values like "elegance" or "efficiency." Human beings are then placed in a reactive position to a form of change over which they have no control. Instrumentalism depicts a similar narrative of progress in a slightly different way. Since technologies are means to socially defined ends, their history can be defined as the adaptation of such means to society's needs and a resulting increase in human agency. Technology "evolves" to provide the necessary instrumentation to meet socially defined goals and this constitutes its "progress." Our idea of "technological fixes" - the idea that for every social problem there is a technical solution - comes from this (cf, Weinberg, 2005).

While they depict progress differently, essentialism and instrumentalism share the belief that there can be no other technology than the one we have. Essentialists see technologies as expressions of abstract science and engineering, while instrumentalists evaluate progress with reference to the assortment of artefacts available at a given time. This is evident, however, only when we use the present as a basis for evaluating the past, or see the past as a series of events leading inexorably to the present. Such a linear history is refuted when we situate historical analysis in the contexts and from the perspectives of those who shaped decision-making in the past. This reveals that multiple pathways for development are often possible, and that these begin from a range of working designs. Where competing designs exist in an area of development, and where each of these can be said to "work" from a technical perspective, something other than efficiency must explain why one design wins out, just as something other than "evolution" seems to be guiding development.

In a classic study of the bicycle, Pinch and Bijker (1984) demonstrate that what we confront as a concrete object was, at its origins, open to multiple iterations (high-wheeled racers, adult tricycles, etc.) each of which corresponded to the meaning that the device had for different users. Racers wanted speed and danger, moralists wanted women to conform to norms of public decency, and the public wanted a secure means of transportation. These "relevant social groups" (Pinch \& Bijker, 1984) each approached the "bicycle" with a different idea of what it was for, what its meaning-in-use was, and, therefore, what features it had to have. The "bicycle" emerges here not on a linear progression from inefficient designs, but as open to wildly different articulations, each one of which could have been standardized as the bicycle. Rather than being tied to linear "progress," artefacts possess "interpretative flexibility": technical form can differ according to the priorities held by the social groups who have a role in shaping its development (Pinch \& Bijker, 1984).

What this means is that we have to analyse technology according to a "principle of symmetry" (Pinch \& Bijker, 1984), which states that, where a number of working designs of an artefact are available, we cannot explain why one succeeds over others with reference to purely technical criteria. Rather, it is the work of social actors in promoting one iteration of the device that plays a decisive role in stabilizing development around a standardized design. And this definition will also correspond to a contingent definition of the practice into which the technology is to be 
integrated. Technology is thus not just invented once, applied to a practice and then refined. Rather it and the practice to which it is addressed are constructed in tandem over time. And so constructivist analysis of technology must trace those processes whereby, through the interpretative work of social groups, an area of development is stabilized. In the case of the bicycle, this process covered a 20 year period, during which designers, user groups and the organs of public communication were involved in a struggle over what the bicycle would be and what its standard form would include as definitive functions (rubber tires, chain drives, rearseating, evenly sized wheels, etc.). The result is the familiar standard form of the bicycle. But its constitution as a result is revealed here as an iterative process comprising interactions between social groups, design features and use contexts. While from the present the alternative designs seem ridiculous, this has little to do with technical function and nothing to do with the inevitability of progress. Rather, it has to do with the significance user groups attribute to design features as they appropriate technologies into their daily practices.

Of course, the flexibility of technology is variable over time, relative to its contexts. Flexibility lessens to the degree that one design is accepted as definitive. This occurs through the employment of "closure mechanisms" through which the attributed meaning of a technology is stabilised along with a design corresponding to it (Bijker, 1993; Misa, 1992). Sometimes, closure occurs in such a fashion as to combine previously divergent interests in a single design. This happened with the bicycle when concerns for speed and safety that had marked an opposition between racers and the public were combined by adding rubber tires and rear-propulsion drives to a balanced frame with equally-sized wheels. This "closure by redefinition of the problem" (Pinch \& Bijker, 1984) is accompanied by "rhetorical closure" - the promotion of a single interpretation of a technology over others. In both cases, stabilization occurs through interventions into popular and official discourses of technology in an effort to promote one way of seeing, integrating and making it. Development is thus revealed as a highly contingent process in which standard forms of rationalized systems are as much the product of interpretation as they are of technical or scientific laws or processes of "evolution" or "progress." This does not mean such laws are meaningless, but rather that what we achieve technically is a product of the attribution of appropriate or desired meanings that contextualise how technical and scientific principles are concretised in actual systems.

What is the significance of these insights for online education? In general, they caution us to frame the historical analysis of educational technologies relative to the interests of the actors involved, and to see our own research not only as a contribution to knowledge, but as a move in controversies around what online education should be. Some have argued, for example, that online education is open to radically different futures, depending on whether we emphasise education's information delivery functions or its socially interactive aspects (Feenberg, 1999b; Hamilton, 2009; Hamilton \& Feenberg, 2006). These possibilities make little sense when seen as strictly technical possibilities. They only gain cogency when situated in relation to social interests and programs of educational change. Administrators facing budgetary constraints might favour technologies that enable the distributed delivery of educational commodities, while educators espousing constructivist pedagogy might require systems that enable student-driven interaction guided by expert facilitators. And the development of online education might bring some interests into collusion with one another while driving others apart. What could be called the general identity of online education is at stake in such debates - and not just at the discursive level, but at that point where discursive understandings are translated into technical 
specifications. In our research, we need to be clear about the value of our definition of online education in relation to the position we occupy in the educational field. We should understand that in researching online education, we are not merely reporting on what exists - we are working to define what might exist in the future.

\section{The separation of technology and values - the social construction of technology}

The foregoing discussion suggests that another assumption common to essentialism and instrumentalism needs to be questioned - their separation of technology from values.

Essentialism claims that the meaning of technology is pre-determined, so posing value questions is moot. If values are specified only with respect to technological essences, then questioning technology on the basis of human values can only appear as opposition to technology as such. Unfortunately, the critique of technology all too often takes this approach, with the result that values defended by critics seem to be external to technology, rather than as a potential underpinning for it (cf, e.g., Noble, 2002). The result is that a potentially fruitful dialogue between pedagogical values, educational philosophy and technological design is cut off - we must simply accept technology and adapt to it or reject it out of hand.

By contrast, instrumentalism states that, since technology is a response to society's needs, there is no tension between technology and values. Rather, the technologies that we have are products of popular demand and free choice, as evidenced by their success in the market. For some, such success stands as sufficient proof of a coincidence between technology and social values, obviating the need for a normative critique. If technologies have bad effects, this is the result of misuse by humans - and so it is in human choices that we must locate our critique, not at the level of technology as such. But, as we have argued, finished artefacts combine both rational structures and socially inflected choices. As such they bear a normative dimension before users confront them. And so neither instrumentalism nor essentialism can ground a normative critique of technology nor admit of how the choice of technology also involves a debate about what kind of future we want.

Constructivist technology studies, in viewing technology as an emergent social process, posits human values not as inalienable to technical essences nor as expressions of consumer preferences, but as contingently built into technologies. If technological development is guided by social influences, then the resulting artefact will be "biased" - that is, it will embody the implicit values of one or more social groups while excluding the interests or perspectives of others (Feenberg, 2002). There are two senses in which technology can express such biases first, in the way a sociotechnical system distributes responsibility across a practice, and second, in the form of the technical systems themselves.

Latour (1992), for example, illustrates how agency is distributed across sociotechnical systems through an analysis of speed bumps. These familiar objects are not merely static structures, but contain a moral precept - "drive safely" - and work to constrain action and choice in line with that precept. They build a moral program into the concrete features of the world. But they also embody assumptions about where the capacity for choice should be located. A sign asking drivers to slow down embodies the same moral prescription as the speed-bump, but leaves decision-making power with drivers, whereas the speed-bump frames decision-making in such a way that, in order to avoid an undesirable outcome (damage to the vehicle), choice is constrained in favour of slowing down. Decision-making is thus "delegated" to the speed-bump and away 
from human agents so as to effectively realize a program of action through the configuration of a sociotechnical system. Something similar is at work in the design of automatic seatbelts, where a contingent moral prescription for driver safety is not just enshrined in a law, but built into the automobile itself as a design feature. We do not have to have such technologies, but we develop them nonetheless relative to a vision we more or less accept of what a good society looks like.

When considering the meaning of technology, then, we need to consider the way that design embodies contingent programs of action and, in doing so, shapes social practices through the delegation of agency between humans and nonhumans. In cases like the speed bump, the fact that agency is delegated to a technical object seems unproblematic since valuing our children's lives is not generally something that is open to wide social debate. In other cases, where debates over the kind of society we have are less universally agreed upon, the situation might be quite different. In online education, for example, it is a matter of great importance, but also some conflict, how decision-making power in the learning process is delegated. Where do we assign functions to the machine and where do these remain with humans? What are the implications of the delegation of agency in one direction or the other? How do technologies distribute agency between the various types of actors involved in education - and what are the implications for these actors of a distribution of agency in one direction or another? These questions have both pedagogical significance and significance for the designers of educational systems and should be at the core of online education research and design. Indeed, it is the answer given to these questions in design that gives specifically educational value to technologies. This insight opens up a high degree of relevance of education research at the level of technological design and opens the possibility that educators reclaim their role as designers of learning environments and processes within new technological contexts.

The "translation" (Callon, 1987) of a program of action into a functioning system results in the design of artefacts that embody assumptions about practices and the actors involved in them. Technologies themselves can thus be said to be "biased" (Feenberg, 2002) to the extent that they are designed according to necessarily limited definitions of the situations to which they are applied. The example of industrial machines designed for children to use illustrates this. Such machines embodied requirements for efficiency that excluded a moral evaluation of the child. Rather they focused on the ergonomics of small bodies and the training of their motive force. This bias does not arise from a sociopathic hatred of children, but from the predominance of an economic logic in making decisions that effect children's lives (Feenberg, 2003). Once the value horizons of industrial labour expand to include a moral evaluation of the child, different design options become not only possible, but desirable. Transformation of the values on which we organize our activities can lead to transformations in the infrastructure mediating those activities.

The lesson is that technical things also have a political inflection. The consequences of technology are different for different groups, and one design may not take into account the perspectives of all. In cases where design excludes certain interests, it may be tempting to oppose technology as such, as many critics of online education do. But a more rational approach can be pursued: namely, advocacy for the redesign of technology to include previously excluded values. This "democratic" rationalization (Feenberg, 1992; Feenberg \& Bakardjieva, 2004) is actually more common than is accounted for in essentialism and instrumentalism. But it requires a reconceptualization of our role as "users" of technology. The everyday contexts of use are not just those in which pre-given functions are implemented. They are also moments in which the 
complex "lifeworld" of our experience, interests, and beliefs comes up against a mode of systematization. They are thus also moments at which we can articulate our own interests relative to the assumptions embodied in technical things. We are not only users of technology, but "participant interests" in the conduct of sociotechnical practices. As such, we can articulate visions for those practices that are not embraced by currently available systems. Where we can link our interests with those of others, we can form a unique kind of historical agency in relation to technology - a basis for the reform of technical systems. Our self-concept as "users" is intrinsically pacifying, where the interests and visions of educators could be represented much more directly in activating our expertise as participants in the design of educational environments and processes.

In sum, the design of technologies makes assumptions about the social world that can be expressed in terms of moral programs or human values. Where these assumptions correspond to or foster disadvantage, the resulting designs work against the interests of excluded groups. But despite the seeming intransigence of this situation, the critique of existing technology does not have to be voiced as rejection. It can be iterated in terms of alternative designs that more adequately address previously excluded concerns. What this cautions for online education research is an expansion of our understandings of the implications of educational technology beyond the space of our classrooms, and a widening of our assessment of their wider implications for the institutional cultures of which we are a part. The development of new technologies should not only orient us towards functional change in educational practice, but to a reflection on the values we espouse as educators. We should be wary of claims that technology necessitates changes in traditional practices and instead try to find that which is worthwhile in such traditions and attempt both to advocate for them and see them as potential foundations for innovation. We need to ask what our values are as educators and how we might envisage these values as operative aspects of online education as a sociotechnical practice. We need to ask not only what technologies can do, but where they fail in relation to our expectations of education.

\section{Conclusion: Reorienting online education research}

Online education originally emerged as a key area of transformation in teaching and learning at a time when higher education was experiencing a set of crises that fostered a particular view of what technology could and should do and what its trajectories of development should be. Shrinking budgets, mounting calls for relevance, increasingly crowded classrooms - amidst these difficulties, online education was framed as a turn-key solution that could create new revenue streams, reduce dependence on costly human resources, expand access, and integrate education to postindustrial society. In this climate, online education became embedded in an "evangelical discourse" (Hamilton, 2009), within which the basic tenets of essentialism and instrumentalism reigned and set the tone for research in the field. In reaction, critics such as Noble (2002) emerged in opposition to online education, identifying it with an agenda of economic rationalization. The result was a standoff between proponents and critics whose foundation was an essentialist identification of technology with a program of institutional reform that was largely espoused by university administrators, corporate CEOs, and futurologists. None of these groups were particularly interested in asking difficult questions about pedagogy, but were only concerned that the mode of education supported by new technologies conformed to their depiction. As long as the essence of technology appeared to be pre-defined, researchers could 
concern themselves with narrow questions of use and the adoption of instrumentalist perspectives relative to the essentialist visions of reformers.

This situation has persisted in online education research, with the result that a whole sphere of inquiry into the pedagogical potential of technology has remained untapped. Scholars with an interest in educational technology have done well, of course, to extend the discussion around educational practice to technology. But we believe that this movement can only progress if it begins to subject technology to the same rigorous questioning to which it has subjected education. We hope that the brief outline of constructivist approaches to understanding technology that we have provided here can act as a starting point for the development of roadmaps through the convergence of education and technology to enliven future research in educational technology.

\section{References}

Ally, M. (2004). Foundations of educational theory for online learning. In T. Anderson \& F. Elloumi (Eds.), Theory and practice of online learning (pp. 3-31). Athabasca, AB: Athabasca University.

Anderson, T. (2004). Toward a theory of online learning. In T. Anderson \& F. Elloumi (Eds.), Theory and practice of online learning (pp. 33-60). Athabasca, AB: Athabasca University.

Bates, A. W. (2000). Managing technological change: Strategies for college and university leaders. San Francisco: Jossey-Bass.

Bereiter, C. (2002). Education and mind in a knowledge society. Mahwah, NJ: Erlbaum.

Bijker, W. (1993). Do not despair: There is life after constructivism. Science, Technology and Human Values, 18(1), 113-138.

Bonk, C. J. \& King, K. S. (Eds.). (1998). Electronic collaborators: Learner-centred technologies for literacy, apprenticeship an discourse. Mahwah, NJ: Lawrence Erlbaum Associates.

Brown, J. S., Collins, \& Duguid, P. (1996). Situated cognition and the culture of learning. In D.P. Ely \& T. Plomp (Eds.). Classical writings on instructional technology (pp. 31-49). Englewood, CO: Libraries Unlimited.

Burton, J. K., Moore, D. M. \& Magliaro, S. (2004). Behaviorism and instructional technology. In D. H. Jonassen (Ed.), Handbook of research on educational communications and technology (2 ${ }^{\text {nd }}$ ed.) (pp. 3-35). Mahwah, NJ: Lawrence Erlbaum.

Callon, M. (1986). Some elements of a sociology of translation: Domestication of the scallops and fishermen of St. Brieuc Bay. In J. Law (Ed.), Power, action, and belief: A new sociology of knowledge? (pp. 196-233). London: Routledge and Keegan Paul.

Callon, M. (1987). Society in the making: The study of technology as a tool for sociological analysis. In T. Pinch, T. P. Hughes, \& W. Bijker (Eds.), The social construction of 
technological systems: New directions in the sociology and history of technology (pp. 83103). Cambridge, MA: MIT Press.

Collis, D.J. (2002). New business models for higher education. In S. Brint (Ed.), The future of the city of intellect: The changing American university (pp. 181-202). Stanford: Stanford UP.

Davenport, P. (2002). Universities and the knowledge economy. In D. Laidler (Ed.), Renovating the ivory tower: Canadian Universities and the knowledge economy (pp. 39-59). Toronto: C.D. Howe Institute.

Feenberg, A. (1989). The written world: On the theory and practice of computer conferencing. In R. Mason \& T. Kaye (Eds.), Mindweave: Communication, computers, and distance education (pp. 22-39). Oxford: Pergamon Press.

Feenberg, A. (1999a). Distance education: Promise or threat? Retrieved from http://www.sfu.ca/ andrewf/TELE3.HTM\#Distance\%20Learning:\%20Promise\% 20or\%20Threat

Feenberg, A. (1999b). Questioning Technology. London: Routledge.

Feenberg, A. (2002). Transforming technology. Oxford: Oxford UP.

Feenberg, A. (2003). Values and the environment. Logos, 2(2), 31-45.

Feenberg, A. \& Bakardjieva, M. (2004). Consumers or citizens: The online community debate. In A. Feenberg \& D. Barney (Eds.). Community in the digital age: Philosophy and practice (pp. 1-30). Lanham, MD: Rowman \& Littlefield.

Fletcher, J.D. (2006). The advanced distributed (ADL) vision and getting from here to there. In H. F. O’Neil \& R. S. Perez (Eds.), Web-based learning: Theory, research and practice (pp. 31-54). Manwah, NJ: Lawrence Erlbaum.

Foster, J., Bowskill, N., Lally, V. \& McConnell, D. (2002). Managing institutional change for networked learning: A multi-stakeholder approach. In C. Steeples \& C. Jones (Eds.), Networked learning: Perspectives and issues (pp. 125-142). London: Springer.

Goodfellow, R. (2007). From "equal access" to "widening participation": The discourse of equity in the age of e-learning. In J. Lockard \& M. Pegrum (Eds.), Brave new classrooms: Educational technology and democracy (pp. 55-74). New York: Peter Lang.

Graves, W.H. (2002). An updated perspective on the NLII agenda. Retrieved from http://net.educause.edu/ir/library/pdf/NLI0244.pdf

Gunawardena, C.N. \& McIsaac, M.S. (2004). Distance education. In D. Jonassen (Ed.), Handbook of research on educational communication and technology (pp. 355-395). Mahwah, NJ: Lawrence Erlbaum.

Hamilton, E. (2009). The automatic student and the robot professor (Unpublished doctoral dissertation). Simon Fraser University, Burnaby, British Columbia, Canada. 
Hamilton, E. \& Feenberg, A. (2006). The technical codes of online education. In J. Lockard \& M. Pegrum (Eds.), Brave new classrooms: Educational democracy and the Internet (pp. 225-249). New York: Peter Lang.

Hamilton, E. \& Feenberg, A. (2012). From commodification to communication: Alternative rationalisations in online education. In N. Friesen \& A. Feenberg (Eds.), Reinventing the Internet: Critical case studies (pp. 43-70). Rotterdam: Sense.

Harasim, L., Hiltz, S. R., Teles, L. \& Turoff, M. (1995). Learning networks: A field guide to teaching and learning online. Cambridge, MA: The MIT Press.

Heidegger, M. (1977). The question concerning technology and other essays (W. Lovitt, Trans.). New York: Harper \& Row.

Heterick, R. C., Mingle, J. R. \& Twigg, C. A. (1998). The public policy implications of a global learning infrastructure. Report from a Joint NLII-SHEEO Symposium. Denver, CO, Nov. 13-14, 1997. Retrieved from http://net.educause.edu/ir/library/html/nli0005.html

Hiltz, S.R. (1994). The virtual classroom: Learning without limits via computer networks. Norwood, NJ: Ablex.

Holmes, B. \& Gardner, J. (2006). eLearning: Concepts and practice. London: Sage.

Hughes, T. P. (1987). The evolution of large technological systems. In T. Pinch, T. P. Hughes, \& W. Bijker (Eds.), The social construction of technological systems: New directions in the sociology and history of technology (pp. 51-82). Cambridge, MA: MIT Press.

Jacobson, M. (2004). Cognitive visualisations and the design of learning technologies. International Journal of Learning Technology, 1(1), 40-62.

Jonassen, D. H. (1996). Objectivism versus constructivism: Do we need a new philosophical paradigm? In D.P. Ely \& T. Plomp (Eds.), Classical writings on instructional technology (pp. 53-63). Englewood, CO: Libraries Unlimited.

Katz, R. \& Oblinger, D. (2000). The 'e' is for everything: E-commerce, e-business and elearning in the future of higher education. Educause Leadership Strategies 2. San Francisco: Jossey-Bass; Educause; Pricewaterhourse Coopers.

Kerr, S. (2004). Toward a sociology of educational technology. In D. Jonassen (Ed.). Handbook of research on educational communications and technology (pp. 113-142). Mahwah, NJ: Lawrence Erlbaum.

Kintsch, E. (1993). Principles of instruction from research on cognition. In J. M. Spector, M. C. Polson \& D. J. Muraida (Eds.). Automating instructional design: Concepts and issues (pp. 23-42). Englewood Cliffs, NJ: Educational Technology Publications.

Lanham, R.A. (2002). The audit of virtuality: Universities in the attention economy. In S. Brint (Ed.), The future of the city of intellect: The changing American university (pp. 159-180). Stanford, CA: Stanford UP. 
Lankshear, C., Peters, M. \& Knobel, M. (2000). Information, knowledge and learning: Some issues facing epistemology and education in a digital age. In N. Blake \& P. Standish (Eds.), Enquiries at the interface: Philosophical problems of online education (pp. 19-43). Oxford: Blackwell.

Latour, B. (1992). Where are the missing masses? The sociology of a few mundane artifacts. In W. Bijker \& J. Law (Eds.), Shaping technology/building society: Studies in sociotechnical change (pp. 225-259). Cambridge, MA: MIT Press.

Latour, B. (1987). Science in action: How to follow scientists and engineers through society. Cambridge, MA: Harvard UP.

Laurillard, D. (1993). Rethinking university teaching: A framework for the effective use of educational technology. London: Routledge.

Lauzon, A. C. (1999). Situating cognition and crossing borders: Resisting the hegemony of mediated education. British Journal of Educational Technology, 30(3), 261-276.

Law, J. (1987). Technology and heterogeneous engineering: The case of Portuguese expansion. In W. Bijker, T. P. Hughes \& T. Pinch (Eds.), The social construction of technological systems: New directions in sociology and history of technology (pp. 111-134). Cambridge, MA: The MIT Press.

Law, J. (1991). Introduction: Monsters, machines and sociotechnical relations. In J. Law (Ed.), $A$ sociology of monsters: Essays on power, technology and domination (pp. 1-25). London: Routledge.

Law, J. (1992). Notes on the theory of the actor-network: Ordering, strategy, and heterogeneity. Systems Practice, 5(4), 379-394.

Massy, W. F. \& Wilger, A. K. (1998). Technology's contribution to higher education productivity. In J. E. Groccia \& J. E. Miller (Eds.), Enhancing productivity: Administrative, instructional and technological strategies (pp. 49-59). San Francisco: Jossey-Bass.

Misa, T. (1992). Controversy and closure in technological change: Constructing Steel. In W. Bijker \& J. Law (Eds.), Shaping technology/building society: Studies in sociotechnical change (pp. 109-139). Cambridge, MA: MIT Press.

Moore, M. G. \& Kearsley, G. (1996). Distance education: A systems view. Belmont, CA: Wadsworth.

Naidu, S. (Ed.). (2003). Learning and teaching with technology: Principles and practices. London: Kogan Page.

Noble, D. (2002). Digital diploma mills: The automation of higher education. Toronto: Between the Lines Press. 
Pinch, T. \& Bijker, W. (1984). The social construction of facts and artifacts: Or how the sociology of science and the sociology of technology might benefit each other. Social Studies of Science, 14(3), 399-441.

Robertson, H.-J. (2003). Toward the theory of negativity: Teacher education and information and communication technology. Journal of Teacher Education, 54(4), 280-296.

Royer, J. M. (Ed.). The cognitive revolution in educational technology. Greenwich, CT: IAP.

Russell, T. L. (1999). The "no significant difference" phenomenon: 248 research re-ports, summaries and papers ( $4^{\text {th }}$ ed.). Raleigh: North Carolina State University.

Scardamalia, M. (2004). CSILE/Knowledge Forum. In A. Kovalchik \& K. Dawson (Eds.) Education and technology: An encyclopaedia (pp. 183-192). Santa Barbara: ABC-CLIO.

Smith, N. (2002). Teaching as coaching: Helping students to learn in a technological world. Educause Review, May/June 2002, 38-47.

Steeples, C. \& Jones, C. (Eds.). (2002). Networked learning: Perspectives and issues. Computer Supported Co-operative Work Series. London: Springer.

Stephenson, J. (2001). Teaching and Learning online: Pedagogies for new technologies. London: Kogan Page.

Wallhaus, R.A. (2000). E-learning: From institutions to providers, from students to learners. In R. Katz \& D. Oblinger. The ' $e$ ' is for everything: E-commerce e-business and e-learning in the future of higher education (pp. 21-52). San Francisco: Jossey-Bass; Educause; Pricewaterhouse Coopers.

Weinberg, A.M. (2005). Can technology replace social engineering? In E. Teich (Ed.). Technology and the future ( $9^{\text {th }}$ ed.) (pp. 23-30). Toronto: Thomson Wadsworth.

Wilson, B. W. (Ed.). (1996). Constructivist learning environments: Case studies in instructional design. Englewood Cliffs, NJ: Educational Technology Publishers.

\section{Authors}

Edward Hamilton is Chair of the School of Communication at Capilano University in North Vancouver, British Columbia .Email: ehamilto@capilanou.ca

Dr. Norm Friesen is Canada Research Chair in E-Learning Practices at Thompson Rivers University in British Columbia, Canada. Dr. Friesen is the author of Re-Thinking E-Learning Research: Foundations, Methods and Practices (2009), and The Place of the Classroom and the Space of the Screen: Relational Pedagogy and Internet Technology (2011). Dr. Friesen is also associate editor of the Journal of Curriculum Studies and E-Learning and Digital Media, and Director of the New Media Studies Research Centre. Email: nfriesen@tru.ca

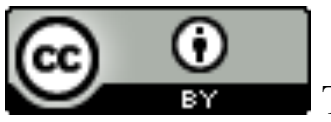

This work is licensed under a Creative Commons Attribution 3.0 License. 